\title{
Interview
}

\section{Language Ideology and the Global Dominance of English. An interview with John O'Regan, Reader in Applied Linguistics at UCL Institute of Education, University College London}

\author{
Alexantra Georgiou \\ UCL Institute of Education, University College London, England
}

Article received 9 October 2016, accepted 23 October 2016, final version 18 March 2017

DOI: http://dx.doi.org/10.5565/rev/jt13.733

\begin{abstract}
Dr. John O'Regan is a Reader in Applied Linguistics at the UCL Institute of Education, University College London. He specializes in World Englishes, intercultural communication and critical discourse analysis, and is the author of articles covering a wide range of topics in applied linguistics and cultural studies.
\end{abstract}

Email: john.oregan@ucl.ac.uk

Interviewer: Do you see any change in the way that scholars in the field study language and language ideologies?

O'Regan: I certainly do see differences in the way scholars approach ideology in relation to language: these are as a result of epistemological differences and perspectives largely around meaning. It was fashionable for a long time to talk about ideology in relation to discourse; often these terms were used interchangeably and without too much reflection on what the distinctions were between ideology and discourse. If you took a perspective that was more aligned with Foucault then you would probably say that ideology and discourse are the same sort of thing, that they are perspectival ways of seeing and knowing. The classical Marxist conception of ideology is that it is a form of false consciousness: that capitalism has effectively made us stupid and has, in the way in which it has arranged social relations, created forms of consciousness which make it difficult for us as human beings to see the reality of our material existence. If people could only see the reality, they would rise up and overthrow the system.

Ideology is often related to this notion of false or distorted consciousness, what Habermas calls distorted communication, that in some way we have been taken away from a path of true awareness of our real conditions of existence. Foucault is interested in understanding how people adopt the identities that they come to adopt in their lives, how people become subjects in relation to issues around power, and how we are always working in 
and through relations of power. Any social institution or context has within it some form of subjectivity so that you have to occupy certain kinds of positions in order for the social event to take on a meaningful character. So, you came here to interview me today and you are occupying the subject position of interviewer, and I am occupying the subject position of interviewee. If I decided to do something completely different and not conform to the subjectivities which have been set up for this situation, and I decided to relate to you as if I were a shop assistant, then this would no longer work very well as an interview.

Interviewer: What would be the consequences if you were not operating based on this?

O'Regan: In order for some kinds of social relations to be meaningful, participants are required to adopt certain roles and functions. Foucault says wherever you can detect regular practices where people speak and act in certain kinds of ways, that is when you can start talking about a formation of practice. For Foucault, the history of humankind is a history of social practices: humans have created ways of thinking, knowing and believing about things which have organised their social practices. He called these discourses. For Foucault, discourse refers to ways of doing and ways of saying. That is what discursive practices are. When you have regularities in these areas, then you also potentially have discursive formations. For example, why is a university, a university? Because in the institution of the university there are all kinds of social practices going on which make this space a university, not a hospital, not a ship - but a university. The key thing for Foucault is that the discursive practices do not necessarily need to be true or false, they just need to be believed in. That is how you construct regimes of truth. This does not mean that the practices or the beliefs are true, only that people believe they are true. This brings us to the difference between discourse and ideology. Foucault would say there isn't any difference because they are just ways of doing and knowing and seeing and being. But he would say that he prefers discourse because the term ideology has a Marxist association with false consciousness, and the idea that it is concealing some kind of truth. But if you do not believe that there is any kind of truth, only practices and beliefs which people adhere to or do not adhere to, then the term ideology is problematic.

Interviewer: How do scholars move beyond the approaches taken by Foucault or Marx?

O'Regan: In thinking about these things scholars are ambivalent. Some prefer ideology, and others prefer discourse, or they use ideology and discourse in synonymous ways. Marnie 
Holborow, for example, prefers to hold onto the term ideology in preference to the term discourse in any Foucauldian sense because of its association with relativism. She sees ideology as having causal effects related to capitalism which construct certain kinds of misleading beliefs and practices. Somebody like Alastair Pennycook would be much more inclined to use the term discourse to refer to these kinds of things than to use ideology.

There is a lot of confusion about ideology. Terry Eagleton gives seventeen different definitions of ideology in his book [Ideology: An Introduction] and one of those that he gives is the classical definition of ideology as false consciousness. This is a very strong definition, because to claim a false consciousness position is to claim you can see the truth that other people cannot see and I think that is somewhat problematic. Nevertheless, I do think that ideology has a property which enables it to become relatively invisible so that people stop noticing it anymore. In this sense, ideology can be thought of as a layered construct in which there are ideological positions that are near the surface so you can see them quite easily, and then there are ideological positions which are much further away and so more difficult to detect. There was recently a referendum in the UK about whether to leave the European Union (EU). Positions which were taken up in relation to Brexit were not very coherent. There was, for example, an anti-immigration position and, opposing this, an 'it will destroy the economy' position. These are ideological positions and it tended to be people who are fairly nationalistic, some might say 'right-wing', who supported the anti-immigration position. The pro-Brexit positions coalesced, as they have done in the United States, into an ideology which was largely anti-immigration, pro-capitalism and pro-neoliberalism. The antiBrexit positions coalesced into an ideology which saw immigration as a benefit to the UK, and which was interested in a more managed welfare approach to capitalism. These are what I call ideologies near the surface. Gramsci was interested in the ideologies that were much further away from the surface. He was interested in how certain kinds of beliefs become normalised so that people no longer question them. They just think it is obvious that circumstances are the way that they are and so if you question that obviousness, people will look at you as if you are taking up a position that does not make sense. It is obvious, so why question it?

In scholarly work from the 1960s and 1970s, in sociology, in political science, in history but also in some aspects of linguistics, such as systemic functional linguistics, Marxist thinking was for a time quite influential. Marxism was very apparent in a lot of the literature. It is very much the opposite now - you get very little explicit reference to it. Part of the reason 
for that is historical. One of the things that the 1989 fall of the Berlin Wall and then the collapse of the Soviet Union in 1991 did, was to enable postmodern and poststructuralist positions to overtake Marxist positions. In the 1990s and 2000s, alongside neoliberalism, we have had a flourishing of postmodernist and poststructuralist positions and the submersion of Marxist positions. Postmodernism and poststructuralism reject the notion of truth, while Marxism has always clung very solidly to a notion that there is some kind of truth to be achieved. What you find with poststructuralists and postmodernists, and then Marxists, is that they nevertheless often talk the same kind of language and offer a similar approach to questioning and critique. One might prefer to use discourse and the other might prefer to use ideology in their writings, but the critique is often quite similar in the way in which they deconstruct certain kinds of discourses or certain kinds of ideologies. In some ways, you can think of postmodernism, poststructuralism and Marxism as being on a similar journey; but with Marxism, there is a destination - a society without exploitation. With poststructuralism and postmodernism there is only interminable questioning, and never-ending critique - there is no final destination. Poststructuralism never lets positions settle. Settling is not good because it leads to the sedimentation or fixing of ideas and beliefs. When you have sedimentation of ideas, people start to believe in the sedimented ideas, and treat them as being the most common-sense ones. That is why poststructuralists are always trying to shake things up. The Marxists want to shake things up too, but with the end of overthrowing capitalism. This is their destination.

Interviewer: You have conducted research on Critical Discourse Analysis in the intercultural context of Islamism, white supremacy and multiculturalism. Do you think that discourses that derive from the UK politicians and the effects of these discourses can be found in other contexts? And how do you think they affect our identities as citizens that come into contact every day?

O'Regan: It is not enough to say there have been discourses or ideologies that have been in circulation in the UK which have then been reconstituted in other contexts such as the USA. It is much bigger than that. However, we did have a debate here about membership of the EU and then a few months later we had the election of Donald Trump, and I do think that there, similar discourses were involved. Indeed, Trump very explicitly made references to how his election was the USA's Brexit moment. There are a lot of parallels between the racism and the anti-immigration rhetoric that marked the Brexit campaign here and Trump's presidential 
campaign in the US. I think that many of the positions that were taken up here lent themselves to some very distasteful positions towards fellow human beings, such as misogyny, racism, and the irrational hatred of others. Across Europe, there are very worrying signs of neo-Nazi and populist parties coming to the fore. But I do not think this is something that is just about the last year or two. As I have said, it is much bigger than that. This is part of an historical process of crisis in the world system. We are now in a new stage of crisis, and each time the crisis becomes acute, as it has now, the system has to find ever more innovative ways for dealing with it. Today, the innovation is to appeal to base instincts such as selfishness and fear as a way of managing the crisis. So what we have seen is a major movement towards more extreme neoliberal perspectives on the economy along with much more nationalistic perspectives on nationhood.

In recent years, we have had some very major crises coming very close together. The oil crisis in the 1970s gave a shock to the global system; then in the 1980s American economic policy introduced another shock - known as the Volcker Shock - when the US Reserve suddenly dramatically increased its interest rates. This was a major cause of the Latin American Debt Crisis, and most of the 1980s and 1990s was spent working that out. Then there was the South East Asian financial crisis of the late 1990s, and then in 2001 you have 9/11. At the same time developing through this period was a widening income disparity between the North and the South and this was pushing more people to migrate northwards. With $9 / 11$, and the consequences this has caused in terms of western foreign policy, enforced migration as a result of economic deprivation and war has speeded up. The amount of migration from the Middle East to the north and from Africa to Europe has massively increased; and from South America to the USA, the same.

Interviewer: Do you think language ideologies are linked with today's crises: economic, political and social?

O'Regan: The economic crises of the 1980s and 1990s reinforced the belief that the way to control crises was primarily through monetary means rather than redistributive means. So that the way to control a crisis in the system was to ensure that money circulation could continue unrestricted. That meant making it easier for people and nations to borrow, and borrowing and credit became a fundamental principle and belief - an ideology and discourse - of the global world system. Closely related to the promulgation of these beliefs is language, and in the present world system it is English which for historical reasons is the supercentral language of 
the system. The supercentrality of English in the system bleeds outwards into ideologies about language and what kind of English it is best to learn. When we say language ideologies, what most people in applied linguistics think of are the beliefs people have about language. So we have the language ideology of native speakerism for example. This is the perception that the best person to learn English from is a native speaker of English. This is not actually true for all kinds of empirical reasons. One is that proficient non-native speakers arguably know the language much better than do native speakers, because they have had to learn it. Then you have language ideologies that promote the idea that the most correct form of English is native speaker English, or standard English. But who supposedly speaks the best standard English? In this ideology or discourse, native speakers do. So native speaker standard English is then associated with being the most correct English. What we are dealing with here are beliefs, not truths. But you always end up somehow back with the native speaker. I think that language ideologies such as these are very closely related to the evolution of global capitalism. The way in which global capitalism has evolved over the last fifty, sixty, seventy years has been to concentrate it on a particular Anglo-American model. Right at the centre of the global economy is the USA as the guarantor of the world system. The United Nations, World Bank, International Monetary Fund, World Health Organisation - all these institutions are in one way or another connected to the centre and they move around like satellites in a world system that has the United States at its core. The international institutions which exist are all part of that system. Because the system is an Anglo-American system, this makes English its linguistic terra firma, and the target form for many governments in the formulation of language policy, and for people in the education of their children.

Interviewer: If we accept that the English language is intrinsic to globalisation, the operating system on which the global economy is based today, how do we perceive its dominance or relevance as a lingua franca in a post-Brexit environment?

O'Regan: My view is that even if we do have some major financial shocks around the corner, English will remain the terra firma of the global capitalist world system because at the present time there is no alternative global infrastructure to replace it. China is an extremely powerful country, militarily and economically. Linguistically, I think the Chinese are very powerful, although not to the extent that Chinese, or Mandarin, will challenge the linguistic infrastructures which have been put in place by the Anglo-American model in all the international institutions of this world, including the EU. There are people in Europe 
suggesting that now that Britain has left the EU, it will be possible to downgrade the use of English as the lingua franca of the European Union. I do not find this tenable, because linguistically whether Britain is in or out is irrelevant. What is relevant is that the USA continues to be the centre of the global world system and the EU is one of the biggest markets in that system. For this reason, I cannot see the EU giving up English, because this is the language the EU trades in with the United States, and with the rest of the world system. Even though French is still a very powerful language globally, I cannot really envisage the countries who have joined the EU in the last ten or fifteen years all falling over themselves to make French the first language of their school system. I don't think it is a question of danger for English, it is more a question of displacement. Do I think that French, or even Chinese, will displace English in the European Union? No, I do not.

Interviewer: May I also ask about classroom interactions? How is discourse is reflected in classrooms, and to what extent do you think it affects teacher and student identity?

O'Regan: There are all kinds of classrooms. In London, classrooms are largely multicultural. There are also classrooms in China or in Japan where you do not have the same kind of multiculturalism and the same kind of immigration as you have in the UK. Multiculturalism has been part of UK education for a very long time and while there has been an increase in immigration in recent years, there have been migrants coming to the UK for a much longer period. There is a lot of experience of dealing with multicultural, multilingual, and diverse classrooms here. In the UK, the medium of instruction is English and children have to learn to be able to function in English. We do have systems in place in our schools to help young learners who are recent arrivals in acquiring the language through after-school classes and additional classes within school. But many learn English as they are schooled. In these circumstances identities are in flux. Belonging or not belonging exists on a kind of continuum. It is not that I belong or I don't belong - most of us are somewhere in between. Those who are closer to feeling a sense of belonging, I assume they are able to feel more ontologically at ease in the cultural or multicultural environment which they find themselves in. They feel comfortable in it and are able to negotiate it, but there are others for whom their sense of belonging is much further away from that position. They feel more alienated. I don't really know what belonging means; you hear people who claim that they are British or claim that they are English. I don't know what that means. I think we have got a lot of problems in society in Britain in relation to the notion of belonging, but we have that problem because 
there are people who insist that there is an ideal way of belonging.

Interviewer: So teachers may present discourses of belonging and make children feel alienated?

O'Regan: Exactly, but teachers are being forced by the government to develop discourses of belonging; and schools have been drawing up lists of ideal British values to demonstrate this. I feel that it is a contradiction, and that the more you emphasise this ideal, the more alienated people will become. You also have the situation where people are bilingual and come from families where the first language is not English. Maybe your mother speaks one language and your father speaks another. You have your school language which is English and you have two additional languages going on. How your identity is affected will be affected by your sense of yourself, your belonging to your home, belonging to your parents' cultures or your parents' identities. So there will always be a tension, some kind of friction or dissonance in identity. If we return to ideology and discourse, the notion of belonging is a construct. It is not so much a question of belonging but a question of feeling less alienated or more alienated. From a Marxist perspective, we are alienated because of capitalism. From a Foucauldian perspective, we are alienated because we realise that the discourses which are circulating, which are positioning us and setting up identities for us, are constructed. This realisation makes us feel alienation, because everything is revealed as a performance. Ideology and discourse enable the suppression of feelings of alienation, but always with an ever-present unease.

\footnotetext{
Author's information:

Alexantra Georgiou is a PhD student at University College London. Her doctoral study examines the linguistic practices of refugee children in a Cypriot primary school. Alexantra also works at the University of Westminster as a Research Assistant for a project investigating how new forms of language emerge among Cypriot Greekspeaking minorities in London.

Email: alexantrageo@gmail.com

To cite this article:

Georgiou, A. (2017). An interview with John O’Regan, Reader in applied linguistics at UCL Institute of Education, University College London. Bellaterra Journal of Teaching \& Learning Language \& Literature, 10(2), 97-104. DOI: http://dx.doi.org/10.5565/rev/jtl3.733
}

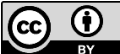

